\title{
THE INFLUENCE OF DIVALENT CATIONS ON ALLOSTERIC BEHAVIOUR OF MUSCLE PYRUVATE KINASE FROM THE SEA MUSSEL MYTILUS EDULIS L.
}

\author{
Albertus de ZwaAn, Dirk A. Holwerda and Albert D. F. Addink \\ Laboratory of Chemical Animal Physiology, State University, 8 Padualaan, \\ Utrecht, The Netherlands
}

(Received 29 August 1974)

\begin{abstract}
Pyruvate kinase of the adductor muscle of the sea mussel displays an absolute requirement for $\mathrm{Mg}^{2+}$ or $\mathrm{Mn}^{2+}$. By the use of $\mathrm{Ca}^{2+}$ or $\mathrm{Zn}^{2+}$ no enzyme activity is obtained.

2. In the presence of $\mathrm{Mn}^{2+}$, in contrast to $\mathrm{Mg}^{2+}$, always hyperbolic substrate saturation curves are obtained.

3. There is evidence that $\mathrm{Mn}^{2+}$ not only acts by forming an ADP-Mn ${ }^{2+}$ complex, but also as an allosteric activator.

4. $\mathrm{Ca}^{2+}$ is a strong inhibitor but the enzyme becomes less sensitive to this inhibition when $\mathrm{Mg}^{2+}$ is replaced for $\mathrm{Mn}^{2+}$.
\end{abstract}

\section{INTRODUCTION}

Mytilus edulis, an intertidal bivalve, keeps its valves tightly closed upon emersion at low tide. During this period of anoxia the animals use a metabolic pathway for energy production which is identical to the Embden-Meyerhof-Parnas scheme up to the stage of phosphopyruvate (PYR-P). In contrast to vertebrate skeletal muscle, which converts PYR-P to pyruvate and accumulates lactate, the main end products are alanine and succinate (De Zwaan et al., 1973). Alanine is the initial end product and its production is restricted to early stages of anoxia. Gradually succinate takes over the position of alanine. The conversion of PYR-P into alanine or succinate depends upon the competition between PYR-P carboxylase (EC 4.1.1.32) and pyruvate kinase (EC 2.7.1.40). For this reason it is clear that pyruvate kinase is a key enzyme in the regulation of anaerobic glycolysis.

Mytilus edulis lives in habitats with fluctuating salinities. The sea mussel behaves as a poikilosmotic organism. In the cell inorganic ions contribute to about $50 \%$ of the osmoconcentration. The rest is made up by taurine, betaine and amino acids (Schoffeniels \& Gilles, 1972). It is likely that carbohydrates form the source for amino acid production (Hammen, 1969). This indicates that pyruvate kinase can play an active role as regulator of free amino acid levels in the cell.

In previous papers (De Zwaan et al., 1972; Holwerda et al., 1973) we studied the influence of organic compounds on pyruvate kinase activity. We found that adductor muscle pyruvate kinase (as well as other tissues as gill, mantle and hepatopancreas) possesses allosteric properties which are similar to $\mathrm{L}$ (liver)-type pyruvate kinase of vertebrate except in its behaviour to $\mathrm{pH}$. We now report about the influence of inorganic ions on pyruvate kinase activity in relation to $\mathrm{pH}$.

\section{MATERIALS AND METHODS}

All (bio)chemicals used were of analytical grade. Sea mussels were obtained from the Institute for Mussel Research (Texel, The Netherlands) and collected from beds in the Waddenzee. Pyruvate kinase was isolated from fresh posterior adductor muscle as described before (De Zwaan et al., 1972). The enzyme preparation, which was preserved in $30 \mathrm{vol} \%$ glycerol, had a specific activity of about 45 $\mu$ mole/min per $\mathrm{mg}$ protein at $\mathrm{pH} 7.6$.

Pyruvate kinase activity was measured according to Bücher \& Pfleiderer (1955). Oxidation of NADH was followed at $25^{\circ} \mathrm{C}$ and at $340 \mathrm{~nm}$ in a Zeiss PM QII spectrophotometer. All tests were performed with $1-3 \mu \mathrm{g}$ protein. The figures presented are calculated for the same protein concentration and are therefore direct comparable. The test medium contained $0.1 \mathrm{M}$ imidazole- $\mathrm{HCl}$ buffer, 67 $\mathrm{mM} \mathrm{KCl}, 0.067 \mathrm{mM} \mathrm{NADH}$ and 36 units LDH (Boehringer from hog muscle, in $50 \%$ glycerol). No interference of glycerol with pyruvate kinase was observed.

\section{RESULTS}

Figure 1 shows the substrate saturation curve at $\mathrm{pH} 7.6$ and 6.2 with $\mathrm{Mg}^{2+}$ as divalent cation. At the higher $\mathrm{pH}$ the curve is slightly sigmoid (Hill coeffcient $\left(\mathrm{n}_{\mathrm{H}}\right): 1.4$ and apparent $K_{m}: 0.25 \mathrm{mM}$ PYR-P). Lowering of the $\mathrm{pH}$ to 6.2 results in a sharp increase in sigmoidicity $\left(\mathrm{n}_{\mathrm{H}}=1.9\right)$ as well in apparent $K_{m}(0.81$ $\mathrm{mM}$ ).

Figure 2 shows the same relation when a fixed amount of FDP $(0.1 \mathrm{mM})$ is added to the reaction medium. At both $\mathrm{pH}$ values there is a decrease of apparent $K_{m}$ (at pH 7.6 apparent $K_{m}=0.07 \mathrm{mM}$, at $\mathrm{pH} 62=0.10 \mathrm{mM}$ ) and of the Hill coefficients. Both curves give a $n_{H}$ of $1 \cdot 1$, reflecting a hyperbolic saturation curve. As can be concluded from Figs. 1 and 2 stimulation of pyruvate kinase by FDP depends on $\mathrm{PH}$ and PYR-P concentration.

Figure 3 presents the same relation as Figs. 1 and 2 , but with $\mathrm{Mg}^{2+}$ replaced by $\mathrm{Mn}^{2+}$. Neither curve 


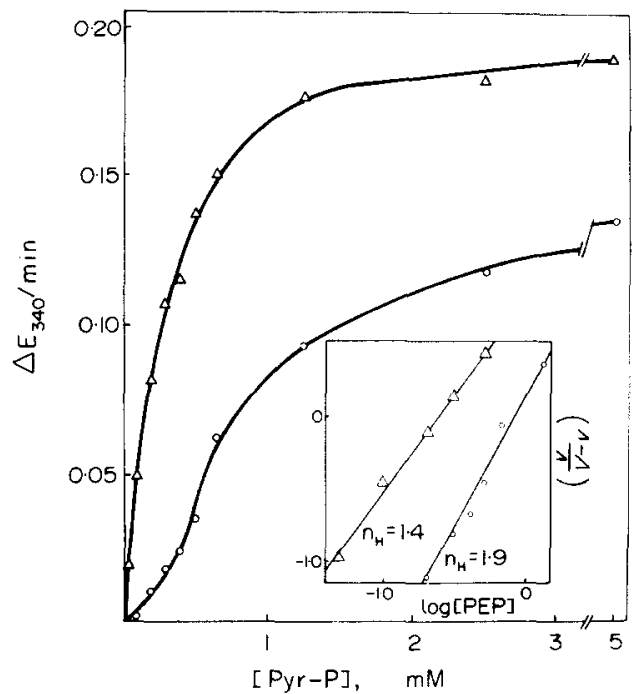

Fig. 1. Relation between pyruvate kinase activity and PYR-P concentration at $\mathrm{pH} 7.6(\Delta)$ and $\mathrm{pH} 6.2(0)$, with $\mathrm{Mg}^{2+}$ as the divalent cation (10 $\mathrm{mM} \mathrm{MgSO}_{4}$ ). A Hill plot is inserted.

exhibits sigmoidicity: Hill coefficients have become $1 \cdot 1$. Addition of FDP has no influence on the activity, neither at $\mathrm{pH} 7.6$ nor at $6 \cdot 2$. Nearly the same apparent $K_{m}$ values are obtained as in the case with $\mathrm{Mg}^{2+}$ in the presence of FDP.

Figure 4 shows $\mathrm{pH}$ optimum curves. With $\mathrm{Mg}^{2+}$ maximal activity is found at $\mathrm{pH} \mathrm{7.4}$. At lower $\mathrm{pH}$ values there is a strong decrease of activity. In the presence of FDP the activity changes only marginally between $\mathrm{pH} 7.5$ and 6.2 . With $\mathrm{Mn}^{2+}$ in the reaction medium instead of $\mathrm{Mg}^{2+}$ the result is completely different: without and with FDP added enzyme activity remains practically constant between $\mathrm{pH} 7.5$ and 6.2 . Also alanine, which is a strong inhibitor when $\mathrm{Mg}^{2+}$ is the divalent ion present (Holwerda et al., 1973), has no influence at any $\mathrm{pH}$ value between 7.5 and $6 \cdot 2$.

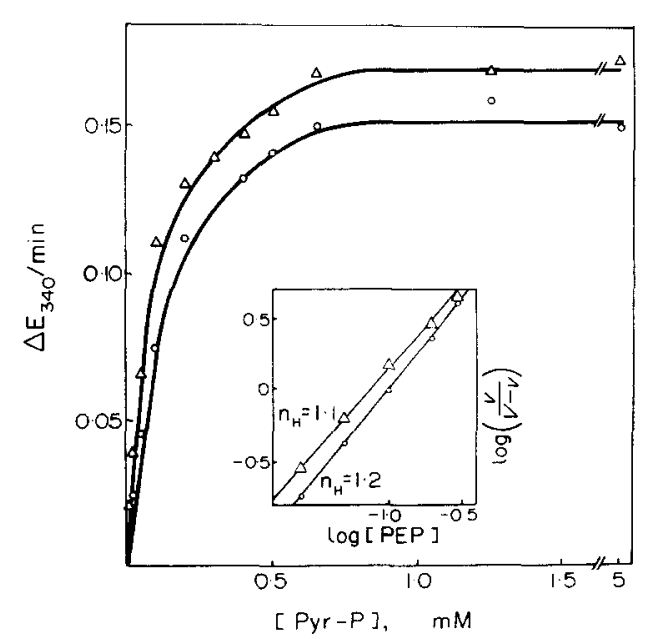

Fig. 2. Relation between pyruvate kinase activity and PYR-P concentration in the presence of $0.1 \mathrm{mM}$ FDP at $\mathrm{pH} 7.6(\triangle)$ and $\mathrm{pH} 6.2(0)$, with $\mathrm{Mg}^{2+}$ as in Fig. 1. A Hill plot is inserted.

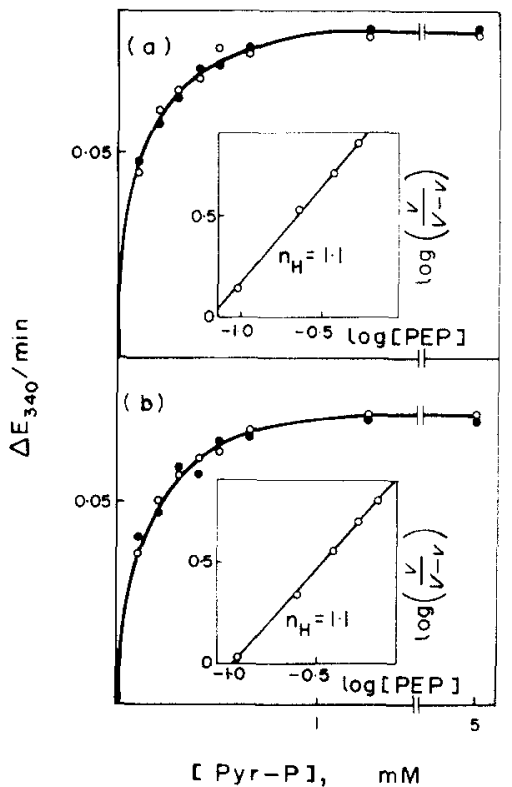

Fig. 3. Relation between pyruvate kinase activity and PYR-P concentration in the presence $(O)$ or absence ( of $0.1 \mathrm{mM}$ FDP. at $\mathrm{pH} 7.6$ (a) and $\mathrm{pH} 6.2$ (b). In all cases $\mathrm{Mn}^{2+}$ was the divalent ion used $\left(10 \mathrm{mM} \mathrm{MnSO}_{4}\right.$ ). Hill plots are inserted

In Fig. 5 saturation curves for the metal ions at $\mathrm{pH} 7.6$ and 6.2 are shown. Values of $V_{\text {max }}$, apparent $K_{m}$ and $\mathrm{n}_{\mathrm{H}}$ have been collected in Table 1 . With $\mathrm{Zn}^{2+}$ or $\mathrm{Ca}^{2+}$ up to $10 \mathrm{mM}$ no enzyme activity was obtained.

Figure 6 shows $\mathrm{Ca}^{2+}$ inhibition curves in the presence of $10 \mathrm{mM} \mathrm{Mg^{2+ }}$ or $\mathrm{Mn}^{2+}$. In the first case the enzyme is strongly inhibited by $\mathrm{Ca}^{2+}\left(K_{\mathrm{i}}=3.6 \mathrm{mM}\right)$ but with $\mathrm{Mn}^{2+}$ the enzyme is almost insensitive to the calcium ion.

Figure 7 shows the activation of pyruvate kinase by $\mathrm{Mn}^{2+}$ in the presence and absence of $5 \mathrm{mM} \mathrm{Mg}^{2+}$ at $\mathrm{pH} 6.2$. It can be seen from Fig. 5 that $\Delta \mathrm{E} / \mathrm{min}$ at $5 \mathrm{mM} \mathrm{Mg}{ }^{2+}$, without $\mathrm{Mn}^{2+}$ added. is 0.03 and

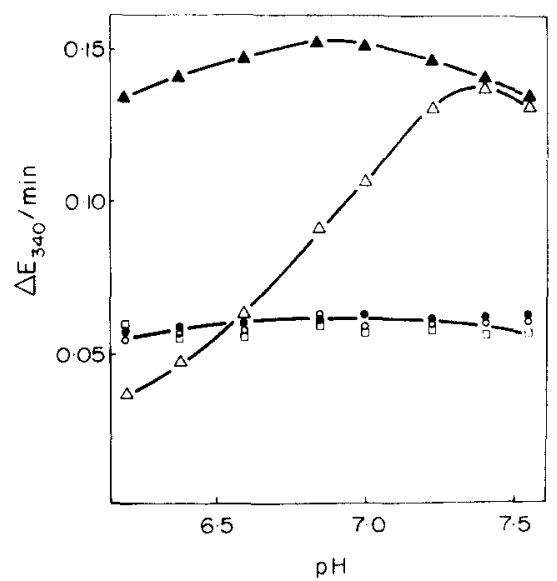

Fig. 4. Effect of the divalent metal ion on the pH optimum curve in the absence and presence of various effectors. $[$ PYR-P] $=0.5 \mathrm{mM} . \triangle 10 \mathrm{mM} \mathrm{MgSO} ;-\triangle 10$ $\mathrm{mM} \mathrm{MgSO}_{4}$ plus $0.1 \mathrm{mM}$ FDP: $\mathrm{O}^{-}-10 \mathrm{mM} \mathrm{MnSO}_{4}$; $\longrightarrow \quad 10 \mathrm{mM} \mathrm{MnSO}_{4}$ plus $0.1 \mathrm{mM} \mathrm{FDP} ; \quad \square-10 \mathrm{mM}$ $\mathrm{MnSO}_{4}$ plus $4 \mathrm{mM}$ alanine. 


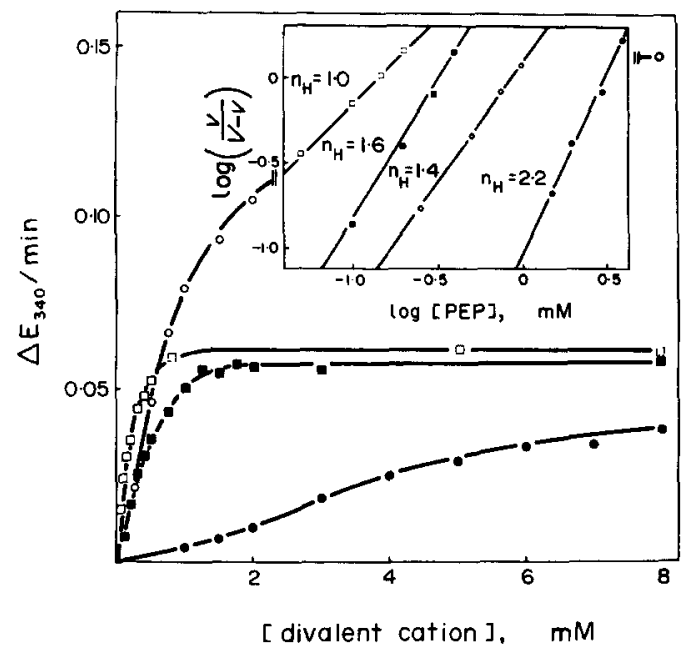

Fig. 5. Activity of pyruvate kinase at $[\mathrm{PYR}-\mathrm{P}]=0.5 \mathrm{mM}$ as a function of $\mathrm{Mg}^{2+}$ concentration $(-\mathrm{O}-\mathrm{pH} 7.6 ;-$ $\mathrm{pH} \mathrm{6.2)} \mathrm{and} \mathrm{Mn}^{2+}$ concentration ( $\square-\mathrm{pH} \mathrm{7.6;- \square -}$ $\mathrm{pH}$ 6.2). Hill plots are inserted.

at saturation concentration of $\mathrm{Mn}^{2+}$, without $\mathrm{Mg}^{2+}$ added, 0.06 (Table 1). So, for the upper curve of Fig. 7 we expected that the reaction velocity would increase from 0.03 to 0.06 (reached when all $\mathrm{Mg}^{2+}$ is replaced by $\mathrm{Mn}^{2+}$ ). But this curve reaches a maximum at a relatively small $\mathrm{Mn}^{2+}$ concentration. This maximum is substantially higher than the maximum for the $\mathrm{Mn}^{2+}$ activation curve.

\section{DISCUSSION}

Pyruvate kinase from the adductor muscle of the sea mussel can exist in two kinetically different forms with a hyperbolic and a sigmoidal saturation curve respectively. The sigmoidal saturation curve can be altered into the hyperbolic by increasing the $\mathrm{pH}$ (Fig. 1), adding FDP (Fig. 2) or replacing $\mathbf{M g}^{2+}$ by $\mathbf{M n}^{2+}$ (Fig. 3). The latter may explain the rapid increase of enzyme activity with increasing concentration of $\mathrm{Mn}^{2+}$ in the presence of $5 \mathrm{mM} \mathrm{Mg}^{2+}$ (Fig. 7, upper curve). From Fig. 5 and Table 1 it is seen that at $\mathrm{pH} 6.2$ both maximal activity and apparent $K_{m}$ of the enzyme for $\mathrm{Mn}^{2+}$ is higher than for $\mathrm{Mg}^{2+}$. So, it was expected that in the presence of $5 \mathrm{mM} \mathrm{Mg}^{2+}$ there would be gradually increase of activity with increasing concentration of $\mathrm{Mn}^{2+}$, since the $\mathrm{ADP}-\mathrm{Mg}^{2+}$ complex becomes replaced by the ADP-Mn ${ }^{2+}$ complex. However, the rapid rise of the upper curve in Fig. - we the middle curce indicates thit not only the complex ADP-Mn' ${ }^{2}$ but also free $\mathrm{Mn}^{2+}$ is responsible for the activation of the enzyme. Free $\mathrm{Mn}^{2+}$

Table 1. Values of $V_{\text {apparent }} K_{m}$ and $\mathrm{n}_{\mathrm{H}}$ of the stimulation curves for $\mathrm{Mg}^{2+}$ and $\mathrm{Mn}^{2+}$ at two $\mathrm{pH}$ values

\begin{tabular}{ccccc}
\hline $\mathrm{pH}$ & Cation & $V_{\max }$ & App. $K_{m}$ & $\mathrm{n}_{\mathrm{H}}$ \\
\hline 7.6 & $\mathrm{Mg}^{2+}$ & 0.15 & 0.87 & 1.4 \\
7.6 & $\mathrm{Mn}^{2+}$ & 0.06 & 0.15 & $1 \cdot 0$ \\
6.2 & $\mathrm{Mg}^{2+}$ & 0.04 & 3.16 & 2.2 \\
6.2 & $\mathrm{Mn}^{2+}$ & 0.06 & 0.46 & 1.6 \\
\hline
\end{tabular}

$V_{\max }$ expressed in $\Delta \mathrm{E} / \mathrm{min}$; apparent $K_{m}$ in $\mathrm{mM}$.

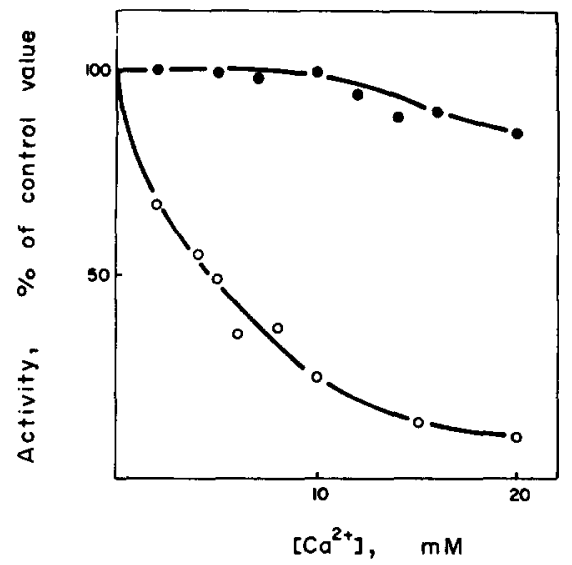

Fig. 6. Inhibition of pyruvate kinase activity by $\mathrm{Ca}^{2+}$ with $10 \mathrm{mM} \mathrm{Mg}^{2+}(-\infty)$ or $10 \mathrm{mM} \mathrm{Mn}^{2+}(--)$ in the reaction medium. $[\mathrm{PYR}-\mathrm{P}]=0.5 \mathrm{mM} ; \mathrm{pH}=7.6$.

could enhance the affinity of the enzyme towards $\mathrm{Mg}^{2+}$ as is the case with increasing the $\mathrm{pH}$ (Table 1). Replacing $\mathrm{Mg}^{2+}$ by $\mathrm{Mn}^{2+}$ and increasing the $\mathrm{pH}$ had also the same effect on the PYR-P saturation curve.

For pyruvate kinase of Mucor rouxii too the manganous ion has been found to be an allosteric activator (Passeron et al., 1969). Recently it has been shown (Leonard, 1972) that for erythrocyte pyruvate kinase $\mathrm{Mn}^{2+}$ changes the sigmoidal substrate saturation curve into a hyperbole and causes desensitization for FDP.

The results presented indicate that changes of pyruvate kinase activity may be the result not only of variations in the concentration of organic substances such as PYR-P, ATP, alanine and FDP, but also in the intracellular concentrations of metal ions. Potts (1958) reported concentrations of 7.3 and $34 \mathrm{mg}$ ion for $\mathrm{Ca}^{2+}$ and $\mathrm{Mg}^{2+}$ respectively in Mytilus edulis. In our laboratory we found the $\mathrm{Mn}^{2+}$ concentration to vary between 0.05 and $0.15 \mathrm{mg}$ ion. This concentration range of the manganous ion is below the apparent $K_{m}$ values presented in Table 1 . This is important as a high concentration of $\mathrm{Mn}^{2+}$ would keep the enzyme in the hyperbolic form with loss of its regulatory properties.

During anoxia in bivalves the $\mathrm{Ca}^{2+}$ concentration increases (Crenshaw et al., 1969). This may play a role in inhibiting pyruvate kinase (Fig. 6), thus leaving PYR-P available for production of succinate.

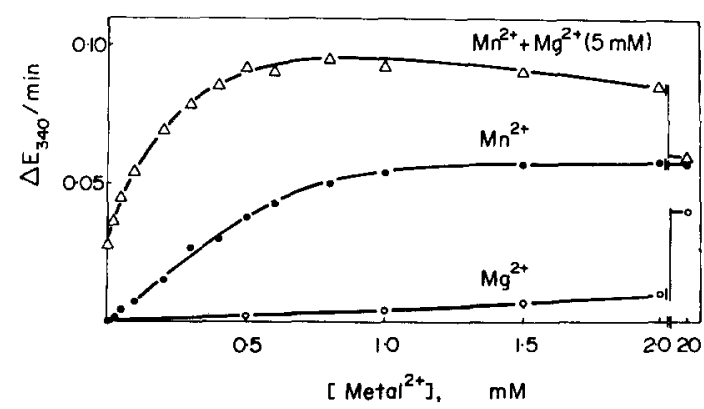

Fig. 7. Effect of variation of the concentration of $\mathrm{Mg}^{2+}$ $(-), \mathrm{Mn}^{2+}(-)$ and $\mathrm{Mn}^{2+}$ plus $5 \mathrm{mM} \mathrm{Mg}^{2+}$ $(-\triangle-)$ on the enzyme activity. [PYR-P] $=0.5 \mathrm{mM}$ $\mathrm{pH}=6 \cdot 2$. 


\section{REFERENCES}

Bücher Th. \& Pfleiderer G. (1955) Pyruvate kinase. In Methods in Enzymology (Edited by Colowick S. P. \& Kaplan N. D. ), Vol. 1. pp. 435 436. Academic Press. New York.

Crenshaw M. A. \& NefF J. M. (1969) Decalcification at the mantle shell interface in molluscs. Am. Zoologist $\mathbf{9}$, $881-885$

Hammen C. S. (1969) Metabolism of the oyster. Crassostrea virginica. Am. Zoologist 9, 309-318.

Holwerda D. A. \& ZWAAN A. DE: (1973) Kinetic and molecular characteristics of allosteric pyruvate kinase from muscle tissue of the sea mussel Mytilus edulis L. Biochim. biophys. Acta 309, 296-306.

LeONARD H. A. (1972) Human pyruvate kinase. Role of the divalent cation in the catalytic mechanism of the red cell enzyme. Biochemistry 11, 4407-4414.

Passeron S. \& Terenzl H. (1969) Activation of pyruvate kinase of Mucor rouxii by manganese ions. Febs Lett. 6. 213216

Potts W. T. W. (1958) The inorganic and amino acids composition of some lamellibranch mussels. $J$. exp. Biol. 35, 749-764.

Schoffenites E. \& Gilles R. (1972) Ionregulation and osmoregulation in Mollusca. In Chemical Zoology (Edited by FLORKIN M. \& SCHELR B. T.), Vol. 6, pp. 393-420, Academic Press, New York

ZWAAN A. DE \& HOLWERDA D. A. (1972) The effect of phosphoenol-pyruvate, fructose-1,6-diphosphate and $\mathrm{pH}$ on allosteric pyruvate kinase in muscle tissue of the bivalve Mytilus edulis L. Biochim. biophys. Acta 276, 430-433. ZWaAN A. DI: \& Marrewij W. J. A. VAN (1973) Anaerobic glucose degradation in the sea mussel Mytilus edulis L. Comp. Biochem. Physiol. 44B, 429-439.

Key Word Index Mytilus edulis: muscle pyruvate kinase; divalent cations; anaerobic metabolism; anoxia. 